\title{
CROSS-COUNTRY EVIDENCE \\ ON THE LINK BETWEEN \\ VOLATILITY AND GROWTH
}

Garey Ramey

Valerie A. Ramey

Working Paper No. 4959

\section{NATIONAL BUREAU OF ECONOMIC RESEARCH 1050 Massachusetts Avenue Cambridge, MA 02138 \\ December 1994}

For helpful comments we are grateful to George Borjas, John Campbell, John Cochrane, James Hamilton, James Rauch, Paul Romer, and two anonymous referees. We are also grateful for financial support from the National Science Foundation, grants SES 90-22947 and SBR 92-10405. This paper is part of NBER's research programs in Economic Fluctuations, Growth, and International Finance and Macroeconomics. Any opinions expressed are those of the authors and not those of the National Bureau of Economic Research.

(C) 1994 by Garey Ramey and Valerie A. Ramey. All rights reserved. Short sections of text, not to exceed two paragraphs, may be quoted without explicit permission provided that full credit, including $\odot$ notice, is given to the source. 


\title{
CROSS-COUNTRY EVIDENCE \\ ON THE LINK BETWEEN \\ VOLATILITY AND GROWTH
}

\begin{abstract}
This paper presents empirical evidence against the standard dichotomy in macroeconomics that separates growth from the volatility of economic fluctuations. In a sample of 92 countries as well as a sample of OECD countries, we find that countries with higher volatility have lower growth. The addition of standard control variables strengthens the negative relationship. We also find that government spending-induced volatility is negatively associated with growth even after controlling for both time- and country-fixed effects.
\end{abstract}

Garey Ramey

Department of Economics, 0508

University of California, San Diego

9500 Gilman Drive

La Jolla, CA 92093-0508
Valerie A. Ramey

Department of Economics, 0508

University of California, San Diego 9500 Gilman Drive

La Jolla, CA 92093-0508

and NBER 
Business cycle theory and growth theory have traditionally been treated as unrelated areas of macroeconomics. Three papers published in the early 1980s, however, changed this perspective. First, Charles Nelson and Charles Plosser (1982) presented evidence that movements in the GNP tend to be permanent, and second, Fynn Kydland and Edward Prescott (1982) and John Long and Charles Plosser (1983) offered new models for analyzing economic fluctuations that integrated growth and business cycle theory. According to these models, output fluctuations are induced by stochastic variations in technology. In a more recent contribution to this literature, Robert King, Charles Plosser, and Sergio Rebelo (1988) incorporate endogenous growth in a real business cycle model, with the result that temporary disturbances to production possibilities can have permanent effects on the path of output.

In these papers, the mean growth rate of output is by construction independent of the variance of the innovations to technology. Little attention has been paid, however, to the effect of business cycle volatility on growth. Furthermore, with the exception of Roger Kormendi and Philip Meguire (1985), the burgeoning literature on the determininants of growth has remained silent on the subject of business cycle volatility. In fact, Robert Lucas (1987) has suggested that the possible returns from understanding business cycles are trivial compared to those from understanding growth. The implicit assumption behind Lucas' argument is the standard dichotomy in macroeconomics: that growth and business cycle volatility are unrelated.

There are many reasons, however, to believe that growth and volatility may be linked, either positively or negatively. For example, theoretical analysis at the firm level suggests that if there are irreversibilities in investment, then increased volatility can lead to lower investment (e.g. Ben Bernanke (1983), Robert Pindyck (1991)). If these types of results carry over to general equilibrium settings, then more volatility can lead to lower growth through its effect on investment. Garey Ramey and Valerie Ramey (1991) argue 
that if firms must commit to their technology in advance, then volatility can lead to lower mean output because firms find themselves producing at suboptimal levels ex post. If lower current output affects the accumulation of resources, then growth is adversely affected.

There are also reasons to believe that growth and output could be positively linked. Fischer Black (1987) has argued that countries may have a choice between high-variance, high-expected-returns technologies and low-variance, low-expected-returns technologies. In such a world, countries with high average growth would also have high variance. Another argument for a positive link concerns precautionary savings (Leonard Mirman (1971)). If there is a precautionary motive for savings, then higher volatility should lead to a higher savings rate, and hence a higher investment rate. Once again, to the extent that higher investment leads to higher growth, we should observe a positive relationship between growth and volatility.

In this paper we conduct an empirical analysis that demonstrates a strong negative link between volatility and growth. Using a panel of 92 countries, as well as a subset of OECD countries, we show that countries with higher volatility have lower mean growth, even after controlling for other country-specific growth correlates. We also estimate the relationship between volatility and growth in a model that controls for both time- and country-fixed effects. To do this, we isolate a measure of government spending volatility that is correlated with the volatility of output across both time and countries. The estimates of the fixed-effects model reveal that government spending fluctuations and volatility are significantly related, and also that volatility continues to have a negative correlation with mean growth; thus our result remains robust to any conceivable controls that vary with time period or country.

One of our most surprising findings is the apparent absence of a role for the investment share in the relationship between volatility and growth. We find that the 
relationship between volatility and growth is unchanged by the addition of the investment share as a control variable. We also find little impact of our measure of volatility on the investment share of GDP.

A number of papers have noted a statistical relationship between volatility and output. For example, in their study of cyclical behavior during the last century in the U.S., Victor Zarnowitz and Geoffrey Moore (1986) point out that the standard deviation of GNP growth tends to be higher during periods of lower growth. Victor Zarnowitz and Louis Lambros (1987) also find that an increase in uncertainty about inflation has a short-run negative effect on GNP growth. Similarly, using his two-state Markov model, James D. Hamilton (1989) demonstrates that the forecast error from an AR(4) is larger if the economy was in a recession in the previous period. Finally, using cross-country comparisons, Roger Kormendi and Philip Meguire (1985) find that higher standard deviations of output growth rates are associated with higher mean growth rates. We will discuss later why we obtain different results.

The paper proceeds as follows. Section I studies the relationship between growth and volatility when we allow volatility estimates to differ across countries but not across time. In Section II, we obtain a measure of volatility that varies both across countries and across time, and explore the relationship of volatility and growth in a model in which we control for both country- and time- fixed effects. Section III concludes.

\section{Cross-Sectional Variation in Volatility}

Our analysis in this section will proceed as follows. We will begin by studying the relationship between growth and volatility in the simplest possible model, and then add different sets of conditioning variables to determine the robustness of the link. We will also distinguish between volatility of growth and volatility of the innovations to growth, 
and study the impact of each on mean growth. We will end the section by discussing the role of investment.

\section{A. Data}

We choose two samples of countries. The first sample consists of 92 countries which have complete data for the period 1960 to 1985 . We require complete data so that the panel is balanced, which is important because we will be measuring variances with respect to time. The data appendix gives the list of countries included. The second sample consists of only 24 OECD countries from 1950 to 1988 . We study the OECD countries as a subset for two reasons: first, this group of countries has the best quality data, so the volatility measures we use will contain less measurement error; and second, we wish to study a set of countries that have arguably similar production technologies. All of the data, except for human capital variables, are from the Robert Summers and Alan Heston (1991) data set. The human capital variables are from Barro (1991) and Barro and Lee (1993).

\section{B. Mean and Volatility of Growth}

To begin, we calculate the simple correlation of growth and volatility. We calculate the mean and standard deviation of per capita annual growth rates over time for each country and examine the cross-country relationship between growth and volatility. The results of a regression of mean growth $\left({\overline{\Delta y_{i}}}_{\mathrm{i}}\right)$ on the standard deviation of growth $\left(\sigma_{\mathrm{i}}\right)$ for the 92 country sample from 1962 to 1985 is: 1

1 The estimation starts in 1962 and 1952 because later we will be including two lags of GDP as control variables, and we wish the time dimension to remained unchanged across specifications. 


$$
\overline{\Delta y}_{\mathrm{i}}=\underset{(7.7)}{0.030-0.154} \underset{(-2.3)}{0 .} \sigma_{\mathrm{i}}, \quad \mathrm{R}^{2}=0.057, \quad \mathrm{t}-\text { statistics in parenthesis }
$$

and for the sample of OECD countries from 1952 to 1988, is:

$$
\overline{\mathrm{y}}_{\mathrm{i}}=\underset{(3.7)}{0.026}+\underset{(0.67)}{0.147} \sigma_{\mathrm{i}}, \quad \mathrm{R}^{2}=0.020, \quad \text { t-statistics in parenthesis. }
$$

As the regressions show, in the 92 country sample there is a negative and statistically significant relationship between growth and volatility. For the OECD country sample, the coefficient is positive, but not significantly different from zero at conventional levels. Thus, in the 92 country sample, there is evidence that countries with higher year-to-year volatility in growth rates tend to have systematically lower growth rates. Figure 1 shows the plot of growth versus volatility for the 92 country sample. The graph shows a clear negative relationship between growth and volatility, that is not induced by a few outliers.

We now examine the relationship between growth and volatility in models that control for other important characteristics of these countries, as well as in models that measure innovation volatility. To this end, we introduce the following econometric framework:

$$
\begin{gathered}
\Delta \mathrm{y}_{\mathrm{it}}=\lambda \sigma_{\mathrm{i}}+\theta \mathrm{X}_{\mathrm{it}}+\epsilon_{\mathrm{it}} \\
\epsilon_{\mathrm{it}}-\mathrm{N}\left(0, \sigma_{\mathrm{i}}^{2}\right), \quad \mathrm{i}=1, \ldots, \mathrm{I}, \quad \mathrm{t}=1, \ldots, \mathrm{T},
\end{gathered}
$$

where $\Delta y_{i t}$ is the growth rate of output per capita for country $i$ in year $t$, expressed as a $\log$ difference; $\sigma_{\mathrm{i}}$ is the standard deviation of the residuals $\epsilon_{i t} ; \mathrm{X}_{\mathrm{it}}$ is a vector of control 
variables; and $\theta$ is a vector of coefficients that is assumed common across countries. ${ }^{2}$ The residuals $\epsilon_{i t}$ represent the deviation of growth from the value predicted based on the variables in $\mathrm{X}$. The variance of $\epsilon, \sigma_{i}^{2}$, is assumed to differ across countries, but not across time. The key parameter of interest is $\lambda$, which links growth to volatility.

In the first specification, the vector $\mathrm{X}_{\mathrm{it}}$ consists of a set of variables identified by Ross Levine and David Renelt (1992) as the important control variables for cross-country growth equations. These variables are (1) the average investment fraction of GDP; (2) initial log GDP per capita; (3) initial human capital; and (4) the average growth rate of population. The first three variables are the only ones that Levine and Renelt found to be robust across specifications. For the sample of 92 countries, the human capital variable is average schooling years in the total population over age 25 in 1960 from Barro and Lee (1993). For the sample of 24 OECD countries, the human capital variable is the percent of the relevant population in secondary schools in 1950 from Barro (1991). In general, we will refer to the set of four variables as the " $\mathrm{L}-\mathrm{R}$ variables."

The residuals of the growth equation are specified in (1b) to be normally distributed with country-specific variances. We estimate the model (1a-b) jointly using a maximum likelihood procedure in which the variances are treated as parameters. The time period begins in 1962 for the first sample and 1952 for the second sample, resulting in a panel of 2208 observations for the first sample, and 888 for the second sample.

We are now prepared to address the following question: conditional on the $L-R$ variables, do annual mean growth rates vary systematically with the standard deviation of growth from the value predicted by the model? The answer is given in Table 1, which presents estimates of the model for both samples. As shown in the upper portion of the table, the standard deviation enters the estimated growth equation with a negative

2 An alternative specification would use the variance in (1a), rather than the standard deviation. In most cases, the specification with the standard deviation produced a slightly better fit. 
coefficient that is statistically significant: in the case of the 92 -country sample, the estimate is -0.211 with a probability value of 0.009 , and in the case of the OECD sample, the estimate of $\lambda$ is -0.385 , with a p-value of 0.055 . Thus, accounting for the standard cross-country explanatory variables actually strengthens the result of a statistically significant negative correlation between growth and volatility. In the case of the OECD sample, including the $L-R$ variables reverses the sign of the correlation relative to the unconditional relationship between growth and volatility. Further investigation showed that the key control variable in this case is initial GDP per capita. If only initial GDP per capita is added to the regression of growth on volatility in the OECD sample, the estimate of $\lambda$ is -0.293 with a $t-$ statistic of -2.03 .

The coefficients on volatility are economically significant as well. The coefficients imply that one-standard deviation of the volatility measure across countries translates into over half of a percentage point of annual per capita growth in the case of the 92 countries, and one-third of a percentage point of annual per capita growth in the case of the OECD countries. In terms of the magnitude of the economic impact of the five right-hand side variables, volatility ranks third after the investment share and initial GDP in the sample of 92 countries, and second after initial GDP in the sample of OECD countries. In the case of the OECD countries, volatility is slightly more important than the investment share.

Note that the negative relationship exists despite the fact that we have controlled for the investment fraction of GDP. If we omit the investment fraction of GDP from the basic specification, the coefficient on $\lambda$ falls slightly (in absolute value) to -0.176 for the $92-$ country sample and rises somewhat to -0.467 for the OECD sample. Thus, there seems to be no systematic effect of controlling for investment. We will present further results on investment at the end of this section.

The lower part of Table 1 shows summary results of the variances across countries, as estimated by the basic specification. For the 92 country sample, Sweden is the lowest 
variance country and Iraq is the highest variance country. Choosing the U.S. as the comparison country, we find that two-thirds of the countries have variance estimates that are significantly different from the U.S. estimate (at the 10 percent significance level). For the sample of OECD countries, half of the countries have variance estimates that are different from the U.S. Thus, there is substantial variation in the volatility across countries and that volatility has a negative relationship with growth. Figure 2 illustrates that relationship for the OECD sample by plotting the averages of mean growth rates against the estimated standard deviations, after removing the effects of the L-R variables. The graph shows a clear negative partial correlation between volatility and growth.

\section{Innovation Variance and Growth}

So far, we have examined the relationship between growth and a measure of volatility that includes both predictable and unpredictable changes in growth. We now investigate the relationship between growth and the variance of innovations to a forecasting equation for growth. This latter measure corresponds more closely to the notion of uncertainty, which is of interest because several of the theories mentioned in the introduction rely on uncertainty. For this analysis, we use our specification in equations (1a) and (1b), but change the nature of the variables included in X. First, because we wish to avoid including future information in the forecasting equation (1a), we use the investment fraction in the initial year of the sample and the growth rate of population in the first two years of the sample, so that all four $L-R$ variables are measured at the beginning of the sample. We also include forecasting variables, which consist of two lags of the log level of GDP per capita, a time trend, a time trend squared, a time trend that starts in 1974, and a dummy variable for 1974 and after. This specification is consistent with a unit root in GDP, a quadratic deterministic trend in GDP, or a broken 
deterministic trend. Hence the results do not depend on assumptions about the nature of the trend in GDP. In our specification, we are thus allowing countries to have different constants in the forecasting equation based on their initial conditions. In a more general specification of the model, the coefficients on these forecasting variables would also be allowed to differ across countries. Such a generalization is computationally infeasible in the jointly estimated model because of the number of parameters. Below we discuss the effect of allowing for country-specific coefficients in the context of a two-step estimation procedure.

Table 2 shows the results for both samples. For the 92-country sample, the coefficient estimate on the innovation standard deviation is similar to the previous estimates, at -0.178 . In the OECD sample, though, the coefficient is much higher at -0.949 . Both estimates are statistically significant, with p-values less than .015 . In both cases, France is the country with the lowest innovation variance. The estimates show that countries with higher innovation variances, as defined by our model, have lower mean conditional growth rates.

We now address a possible alternative explanation for these results. The restriction that all countries share the same coefficients on the forecasting variables in the growth equation could conceivably induce a spurious correlation: countries that have coefficients very different from the mean, and hence are estimated to have large residuals, might also happen to be slow-growing countries. We could investigate this issue by allowing for country-specific coefficients on the forecasting variables in (1a), but joint estimation is computationally infeasible. Instead we use the following two-step procedure: in the first step, we construct innovations by estimating separate growth forecasting equations for each country, containing a constant term, two lags of GDP and the four trend variables. From these estimated residuals we calculate the standard deviation of the innovation for each country, and then estimate (1a), which includes the $L-R$ variables and forecasting 
variables, by ordinary least squares using the full panel. The second part of Table 2 shows the estimates of $\lambda$ from this procedure. In the case of the 92 -country sample, the estimate is -0.113 with a heteroscedastic-consistent $t$-statistic of -0.73 . Thus, with this method the coefficient remains negative, but the magnitude of the coefficient falls by a third and the standard error doubles, so that the coefficient is no longer significant at conventional levels. In the case of the OECD countries, though, the estimate is very similar to the maximum likelihood estimate, and remains very significant. Thus, the qualitative results are not substantially altered when the standard deviations are estimated using country-specific forecasting equations.

At face value our results seem to contradict those of Kormendi and Meguire (1985). Using a sample of 47 countries from 1950-1977, Kormendi and Meguire regress growth rates on a group of explanatory variables, one of which is the standard deviation of output growth. They find that the standard deviation has a significant positive effect on growth. In these regressions, though, they also include other variables, one of which is the standard deviation of monetary shocks, which has a significant negative effect on growth. The standard deviation of monetary shocks may be correlated with the standard deviation of the innovations to output growth. Thus, in their regressions, the positive effect of the standard deviation of output may be capturing the effect of predictable movements in growth, which depend in large part on the persistence of output growth. To investigate whether our data revealed the same effect, we used our two-step procedure and included both the standard deviation of the innovations and the standard deviation of the fitted values in our model with the $L-R$ variables and forecast variables. In the 92 -country sample, the coefficient on the standard deviation of the innovations was estimated to be -0.072 with a $t$-statistic of -0.35 , whereas the coefficient on the standard deviation of the fitted values was -0.044 with a $t$-statistic of -0.29 . Thus, both types have negative coefficients, but are estimated very imprecisely. On the other hand, for the OECD sample, 
the coefficient on volatility of the innovations was -1.223 with a $t$-statistic of -3.97 and the coefficient on the volatility of the fitted values was 0.659 with a t-statistic of 1.89 . Thus, in the OECD sample we obtain results that are consistent with those of Kormendi and Meguire: volatility of the innovations seems to have a negative effect, while volatility in the predicted variable has a positive effect. Because most movements in growth are unpredictable, measures of combined volatility have a negative net effect. For the remainder of the paper we will concentrate on volatility of the innovations.

\section{Volatility and Investment}

Several of the theories discussed in the introduction link volatility to growth via investment. In the preceding estimates of the relationship between mean and standard deviation of growth rates, however, the results were essentially unaltered by inclusion of an investment control variable. We now give further evidence that investment does not seem to be an empirically important conduit between volatility and growth. The top part of Table 3 shows the estimates of $\lambda$ when the base regression of Table 2 is altered by varying the investment share variable. The first row repeats the estimate of $\lambda$ for each sample from Table 2, which uses the initial year share of investment. The second row reports the results of a specification in which average investment share over the entire sample is used, and the third row reports the results when the investment share is omitted entirely. In each case, the estimate of $\lambda$ is essentially unchanged.

We next assess whether innovation volatility is significantly related to investment. The bottom part of Table 3 shows the results of cross-country regressions of the average investment share on the standard deviation; the latter is estimated according to the specification of Table 2 , in which the average investment share is included. In the simple bivariate specification, innovation volatility appears to have a negative relationship with 
investment, and is significant at the 10 percent level in the case of the 92 countries, but not in the OECD countries. The second row, however, shows that once the other Levine-Renelt variables are included in the investment equation, the effect is no longer significant. Thus, there is little evidence that the investment share of GDP is linked to the innovation variance.

The results of this section and the previous sections give a clear pattern. There is a strong negative link between volatility, particularly innovation volatility, and growth. Moreover, little of the effect seems to flow through investment.

\section{Panel Variation in Volatility}

Levine and Renelt (1992) have shown that the bulk of variables that have been linked to growth in cross-country regressions are not robust to the inclusion of different country-specific control variables. In this section, we further investigate the robustness of our findings to country-specific controls by fully exploiting the panel nature of our cross-country data set. In particular, we isolate a variable that is associated with significant variation in volatility across both time and countries, and then examine the effect of this variable in a model that includes both time- and country-fixed effects. By including dummy variables for each country, we are controlling for the effect of every country-specific variable that could be included. Thus our robustness test is much more stringent than that used by Levine and Renelt.

The first step is to find a variable that affects the volatility of output across time and countries. There are many possible sources of volatility; we investigate government spending as a source of volatility. Thus, we begin by estimating country-specific forecasting equations for government spending growth that contain a constant term, two lags of the log level of GDP per capita, two lags of the log level of government spending per 
capita, a quadratic time trend, a post-1973 trend, and a dummy variable for the post-1973 period.

We next investigate whether the variances of the innovations in the growth equation are related to the squared forecast residuals of the government spending equation. If they are related, then we have a measure of volatility that varies across both time and countries. We can then determine whether there is a negative relationship between volatility and growth, after including time- and country-fixed effects. It is important to note that government spending volatility need not be exogenous for our procedure; we are simply using government spending volatility to obtain an estimate of output volatility that varies over time and across countries. Exogeneity would be important, though, if one wished to make structural inferences.

We estimate the following system of equations linking squared innovations to government spending to output innovation volatility and growth:

$$
\begin{gathered}
\Delta \mathrm{y}_{\mathrm{it}}=\lambda \sigma_{\mathrm{it}}+0 \mathrm{X}_{\mathrm{it}}+\epsilon_{\mathrm{it}} \\
\epsilon_{\mathrm{it}}-\mathrm{N}\left(0, \sigma_{\mathrm{it}}^{2}\right), \quad \sigma_{\mathrm{it}}^{2}=\alpha_{0}+\alpha_{1} \hat{\mu}_{\mathrm{it}}^{2}
\end{gathered}
$$

where $\Delta \mathrm{y}_{i t}$ is the growth rate of output, $\sigma_{i t}$ is the standard deviation of the residual $\epsilon_{i t}$ ' $\mathrm{X}_{\mathrm{it}}$ is a vector of control variables, and $\hat{\mu}_{\mathrm{it}}^{2}$ is the square of the estimated residual for country $\mathrm{i}$ in period $\mathrm{t}$ from the government spending forecasting equations discussed above. The two parameters of interest are $\alpha_{1}$, which shows how the squared innovations to government spending are related to the variance of the output growth innovations, and $\lambda$, which relates the standard deviation of the output growth innovations to the output growth rate.

The results are shown in Table 4. The first column shows the estimates when the 
four L-R variables, a constant term, two lags of the log of GDP and the four trend variables are included in $\mathrm{X}_{\mathrm{it}}$. The estimates of the coefficients on the control variables are not shown in order to conserve space. The estimates of $\lambda$ and $\alpha_{1}$ suggest that not only are the variances of the growth innovations significantly related to the squared innovations in government spending, but that volatility has a negative partial correlation with output growth. The p-value is 0.14 for the 92 -country sample and 0.05 for the OECD sample.

The second column shows the estimates of the model when country-fixed effects (i.e. country dummy variables) are included in $\mathrm{X}_{\mathrm{it}}$, in addition to the forecasting variables included in the first column. By including fixed effects, we are removing any effect of volatility on growth that occurs because of differences in the average growth rates across countries. This specification rules out the possibility that the observed negative correlation between volatility and growth is due to some unobserved characteristic of countries that is leading volatility and growth to move in opposite directions. In the case of the 92 countries, $\lambda$ falls in magnitude, but remains negative, though it is not significant at conventional levels. For the OECD countries, the inclusion of country-fixed effects changes the coefficient only slightly and it remains significant at the seven percent level. Thus, the negative relationship between volatility and growth cannot be accounted for by unobserved country characteristics.

The estimates in the third column show the effect of including time fixed effects (year dummy variables), the L-R variables, a constant term and two lags of log GDP, but no country fixed effects. Including these time dummy variables removes any correlation between volatility and growth that arises from events that impact across countries, such as oil price shocks. The estimates here are again almost identical to the earlier estimates in column (2) and are generally significant.

The fourth column of Table 4 shows the effect of including both time- and country-fixed effects. The estimates of this equation answer the following question: after 
removing both the cross-country and aggregate time variation in the conditional mean growth rates and the volatility measures, is higher volatility linked to lower growth? In other words, is the deviation of output growth from its country and time means negatively associated with the deviation of volatility from its country and time means? The estimates indicate that the answer is affirmative: the estimated values of $\lambda$ are close to those of the preceeding co- $_{-}^{1}$ mmns and are significant at conventional levels in the OECD sample.

Finally, the last column of Table 4 shows the effects of adding controls for government spending growth to the specification having both time and country fixed effects. We include this variable in case our measure of government spending volatility is capturing some of the mean effects. In both cases, the coefficients on the standard deviation variable are very similar to the previous specifications, and are significant for the OECD sample.

The set of results for the OECD sample is striking: not only are government spending volatility and output volatility strongly linked, but even after including both timeand country-fixed effects, volatility has a strong negative relationship with growth that is statistically significant. Further, the relationship appears to be extremely robust, as the estimated coefficients on the volatility measure barely change across specifications.

\section{Conclusion}

We have shown that the standard dichotomy in macroeconomics between growth and the volatility of economic fluctuations is not supported by the data. In a sample of 92 countries as well as a sample of OECD countries, we find that countries with higher volatility have lower growth. Adding control variables strengthens the relationship. We also discover, however, that the investment share of GDP seems to play little role in the link between volatility and growth. Including the investment share as a control variable 
has no impact on the relation.

We find that the negative effect of volatility stems mainly from volatility of innovations to GNP growth, which reflects uncertainty. We also investigate the relationship between growth and volatility in a model in which the variance of innovations to output is linked to the variance of innovations to government spending. For the OECD panel of countries, we find a significant negative relationship between volatility and growth, even when we include both country-and time-fixed effects.

We believe that there are two main conclusions to be drawn from these results. First, by assuming no interaction between volatilty and growth, the theoretical business cycle and growth literatures omit important elements. These omissions can lead to questionable conclusions, such as Lucas' calculation of the potential benefits of eliminating business cycle volatility. Second, investment-based theories of the link between volatility and growth do not seem to be verified by the data.

The results do provide broad corroboration of the theoretical ideas of Ramey and Ramey (1991), who trace the costs of volatility directly to uncertainty-induced planning errors by firms. A related cost of volatility would arise in models in which it is costly to shift productive factors between sectors, such as Guiseppe Bertola (1994) and Avinash Dixit and Rafael Rob (1994). Our results highlight the importance of obtaining a clearer understanding of how rigidities and uncertainty interact to impose costs that take the form of ex post inefficiencies.

Our finding of a negative impact of government spending volatility on growth is complementary to the results of Alberto Alesina, Sule Ozler, Nouriel Roubini and Phillip Swagel (1992), who study the link between political instability and growth. Alesina et al. estimate a model in which political instability and economic growth are jointly determined, and find that more political instability leads to lower growth. Political instability may in fact be an important source of volatility in government spending. 


\section{Data Appendix}

All of the data for the cross-country panel are from the Summers-Heston data set, except for the variable on human capital. The variables used are defined as follows:

Output. Log of Summers-Heston variable "Real GDP per capita, 1985 international prices; Chain index (RGDPCH)." Summers and Heston (1991) recommend using this variable for making intertemporal comparisons, i.e., for studying growth rates across countries over time.

Initial Output. Log of Summers-Heston variable "Real GDP per capita, 1985 international prices; Laspeyres index; RGDP2." Summers and Heston (1991) recommend using this variable for comparing output across countries at one point in time.

Population Growth. The log difference of Summers-Heston population variable.

Investment Share of GDP. Summers-Heston "real Gross Domestic Investment, private and public; \% of RGDCH; 1985 international prices" divided by 100 .

Real Government Spending. Log of Summers-Heston "Real Government, public consumption, \% of RGDPCH; 1985 international prices (g)" multiplied by RGDPCH.

Human Capital. For the 93 country panel, we use the average schooling years in the total population over age 25 in 1960 from Barro and Lee (1993). For the OECD sample, we use we use secondary schooling from Barro (1991). 
List of 92 Countries

\begin{tabular}{|c|c|c|c|c|c|c|c|}
\hline \multirow[t]{2}{*}{ COUNTRY } & & \multicolumn{2}{|c|}{ GROWTH } & \multirow[t]{2}{*}{ COUNTRY } & \multicolumn{3}{|c|}{ GROWTH } \\
\hline & & IEAN & S.D. & & & MEAN & S.D. \\
\hline ALGERIA & $\mathrm{DZA}$ & 3.34 & 11.64 & BOTSWANA & BWA & 6.85 & 7.39 \\
\hline GHANA & GHA & -0.97 & 5.08 & KENYA & $\mathrm{KEN}$ & 1.76 & 5.58 \\
\hline LESOTHO & LSO & 5.35 & 8.46 & LIBERIA & LBR & -0.83 & 6.22 \\
\hline MALAWI & MWI & 0.88 & 5.31 & MAURITIUS & MUS & 2.19 & 5.87 \\
\hline MOZAMBIQUE & $\mathrm{MOZ}$ & -2.06 & 7.91 & NIGER & NER & 0.088 & 8.46 \\
\hline SENEGAL & SEN & -0.057 & 4.59 & SIERRA LEONE & SLE & 0.47 & 5.99 \\
\hline SOUTH AFRICA & $\mathrm{ZAF}$ & 1.64 & 4.87 & SUDAN & SDN & -0.29 & 7.59 \\
\hline SWAZILAND & SWZ & 1.59 & 7.51 & TANZANIA & $\mathrm{TZA}$ & 2.55 & 5.38 \\
\hline TOGO & TGO & 1.95 & 6.61 & TUNISIA & TUN & 3.18 & 3.43 \\
\hline UGANDA & UGA & 0.83 & 12.59 & ZAIRE & ZAR & 0.035 & 7.51 \\
\hline ZAMBIA & ZMB & -1.73 & 7.11 & ZIMBABWE & ZWE & 1.68 & 6.19 \\
\hline BARBADOS & BRB & 2.47 & 4.83 & CANADA & CAN & 2.76 & 2.98 \\
\hline COSTA RICA & CRI & 2.14 & 3.76 & DOMINICAN REP. & DOM & 2.44 & 6.77 \\
\hline EL SALVADOR & SLV & 1.34 & 4.90 & GUATEMALA & GTM & 1.11 & 2.86 \\
\hline HAITI & HTI & 0.24 & 4.13 & HONDURAS & HND & 1.36 & 3.60 \\
\hline JAMAICA & JAM & 1.09 & 4.99 & MEXICO & $\mathrm{MEX}$ & 2.55 & 3.88 \\
\hline NICARAGUA & NIC & 0.10 & 13.35 & PANAMA & PAN & 3.28 & 3.45 \\
\hline TRINID\&TOBAG & TTO & 1.57 & 8.80 & USA & USA & 2.14 & 2.59 \\
\hline ARGENTINA & $\mathrm{ARG}$ & 0.41 & 4.24 & BOLIVIA & $\mathrm{BOL}$ & 1.3 & 4.08 \\
\hline BRAZIL & BRA & 2.89 & 4.79 & CHILE & CHL & 0.63 & 6.16 \\
\hline COLOMBIA & $\mathrm{COL}$ & 2.23 & 3.04 & ECUADOR & ECU & 2.67 & 4.94 \\
\hline GUYANA & GUY & -1.12 & 9.67 & PARAGUAY & PRY & 2.68 & 5.15 \\
\hline PERU & PER & 0.84 & 4.95 & URUGUAY & URY & 0.13 & 5.04 \\
\hline VENEZUELA & VEN & 1.51 & 6.51 & AFGHANISTAN & $\mathrm{AFG}$ & -0.28 & 4.26 \\
\hline BANGLADESH & $\mathrm{BGD}$ & 0.39 & 8.17 & BURMA & BUR & 2.75 & 5.45 \\
\hline HONG KONG & $\mathrm{HKG}$ & 5.97 & 4.05 & INDIA & IND & 0.75 & 3.62 \\
\hline IRAN & IRN & 2.64 & 11.21 & IRAQ & IRQ & 0.88 & 17.47 \\
\hline ISRAEL & ISR & 3.21 & 4.48 & JAPAN & JPN & 5.24 & 3.62 \\
\hline JORDAN & JOR & 2.47 & 7.35 & S. KOREA & KOR & 5.84 & 4.49 \\
\hline MALAYSIA & MYS & 3.92 & 4.33 & NEPAL & NPL & 0.89 & 4.14 \\
\hline PAKISTAN & PAK & 2.21 & 3.82 & PHILIPPINES & PHL & 1.53 & 3.78 \\
\hline SINGAPORE & SGP & 5.90 & 4.46 & SRI LANKA & LKA & 1.71 & 5.09 \\
\hline SYRIA & SYR & 4.13 & 10.25 & TAIWAN & $\mathrm{OAN}$ & 6.28 & 3.03 \\
\hline THAILAND & THA & 3.82 & 2.97 & AUSTRIA & AUT & 3.27 & 1.90 \\
\hline BELGIUM & BEL & 2.72 & 2.50 & CYPRUS & CYP & 4.62 & 10.02 \\
\hline DENMARK & DNK & 2.72 & 2.83 & FINLAND & FIN & 3.31 & 3.12 \\
\hline FRANCE & FRA & 2.97 & 2.04 & W. GERMANY & DEU & 2.59 & 2.42 \\
\hline GREECE & GRC & 4.17 & 3.84 & ICELAND & ISL & 3.37 & 4.09 \\
\hline IRELAND & IRL & 2.39 & 2.87 & ITALY & ITA & 3.35 & 2.76 \\
\hline MALTA & MLT & 5.56 & 4.17 & NETHERLANDS & NLD & 2.70 & 2.41 \\
\hline NORWAY & NOR & $3 . € 1$ & 1.84 & PORTUGAL & PRT & 4.01 & 4.66 \\
\hline SPAIN & ESP & 3.08 & 3.51 & SWEDEN & SWE & 2.49 & 1.81 \\
\hline SWITZERLAND & $\mathrm{CHE}$ & 1.53 & 2.44 & TURKEY & TUR & 2.66 & 3.60 \\
\hline UK & GBR & 2.06 & 2.20 & YUGOSLAVIA & YUG & 3.92 & 4.49 \\
\hline AUSTRALIA & AUS & 2.45 & 2.57 & FIJI & FJI & 1.54 & 5.42 \\
\hline NEW ZEALAND & NZL & 1.46 & 3.29 & PAPUA N.GUINEA & PNG & 1.34 & 5.72 \\
\hline
\end{tabular}




\section{References}

Alesira, Alberto, Ozler, Sule, Roubini, Nouriel, and Swagel, Phillip, "Political Instability and Economic Growth." NBER working paper 4173, September 1992.

Barro, Robert J., "Economic Growth in a Cross-Section of Countries." Quarterly Journal of Economics, May 1991, 106(2), pp. 407-44.

Barro, Robert J. and Jong-Wha Lee, "International Comparisons of Educational Attainment." Journal of Monetary Economics, December 1993, 32(3), 363-394.

Bernanke, Ben S., "Irreversibility, Uncertainty,, and Cyclical Investment." Quarterly Journal of Economics, February 1983, 98(1), pp. 85-106.

Bertola, Guiseppe, "Flexibility, Investment, and Growth," Journal of Monetary Economics, October 1994, 34(2), pp.215-238.

Black, Fischer, Business Cycies and Equilibrium. Cambridge, Mass.: Basil Blackwell, Inc., 1987.

Dixit, Avinash, and Rafael Rob, "Switching Costs and Sectoral Adjustments in General Equilibrium with Uninsured Risk," Journal of Economic Theory, February 1994, $62(1)$, pp. $48-69$.

Hamilton, James D., "A New Approach to the Economic Analysis of Nonstationary Time Series and the Business Cycle." Econometrica, March 1989, 57(2), pp. $357-84$.

King, Robert, Charles Plosser, and Sergio Rebelo, "Production, Growth, and Business Cycles: II. New Directions," Journal of Monetary Economics, March/May 1988, 21 , pp. 309-342.

Kormendi, Roger and Meguire, Philip, "Macroeconomic Determinants of Growth: Cross Country Evidence." Journal of Monetary Economics, September 1985, 16(2), pp. $141-63$.

Kydland, Fynn, and Edward Prescott, "Time to Build and Aggregate Fluctuations," Econometrica, November 1982, 50, pp. 1345-1370.

Levine, Ross, and David Renelt, "A Sensitivity Analysis of Cross-Country Growth Regressions." American Economic Review, September 1992, 82(4), pp. 942-63.

Long, John, and Charles Plosser, "Real Business Cycles," Journal of Political Economy, 1983, 91, pp. 1345-1370.

Lucas, Robert, Models of Business Cycles. Oxford, UK: Easil Blackwell, 1987.

Mirman, Leonard, "Uncertainty and Optimal Consumption Decisions," Econometrica, January $1971,39(1), 179-185$.

Nelson, Charles, and Charles Plosser, "Trends and Random Walks in Macroeconomic Time Series: Some Evicence and Implications," Journal of Monetary Economics, 
1982, 10, pp. 139-162.

Pindyck, Robert S., "Irreversibility, Uncertainty, and Investment," Joumai of Ecoromic Literature, September 1991, 29(3), pp. 1110-48.

Ramey, Garey, and Ramey, Valerie A., "Technology Commitment and the Cost of Economic Fluctuations." Working Paper No. 3755, National Bureau of Economic Research, June 1991.

Summers, Robert and Heston, Alan, "The Penn World Table (Mark 5): An Expanded Set of International Comparisons, 1950-1988." Quarterly Journal of Economics, May 1991, 106(2), pp. 327-68.

Zarnowitz, Victor and Lambros, Louis, "Consensus and Uncertainty in Economic Prediction." Journal of Political Economy, June 1987, 95(3), pp. 591-621.

Zarnowitz, Victor and Moore, Geoffrey, "Major Changes in Cyclical Behavior," in Robert J. Gordon, ed. The American Business Cycle: Continuity and Change, Chicago: University of Chicago Press, 1986. 
Table 1

Relationship beiween Mean Growth and Volatility

(Conditional on Levine-Renelt Variables)

( $t$-statistics in parentheses)

\begin{tabular}{|c|c|c|}
\hline & $\begin{array}{l}92 \text { Country Sample } \\
\text { (2208 observations) }\end{array}$ & $\begin{array}{l}\text { OECD Country Sample } \\
\text { (888 observations) }\end{array}$ \\
\hline constant & $\begin{array}{l}0.0727 \\
(3.72)\end{array}$ & $\begin{array}{r}0.158 \\
(5.73)\end{array}$ \\
\hline volatility $(\sigma)$ & $\begin{array}{r}-0.211 \\
(-2.61)\end{array}$ & $\begin{array}{r}-0.385 \\
(-1.92)\end{array}$ \\
\hline $\begin{array}{l}\text { Average investment } \\
\text { share of GDP }\end{array}$ & $\begin{array}{r}0.127 \\
(7.63)\end{array}$ & $\begin{array}{r}0.069 \\
(2.76)\end{array}$ \\
\hline $\begin{array}{l}\text { average population } \\
\text { growth rate }\end{array}$ & $\begin{array}{r}-0.058 \\
(-0.38)\end{array}$ & $\begin{array}{r}0.212 \\
(0.70)\end{array}$ \\
\hline initial human capital & $\begin{array}{l}0.00078 \\
(1.18)\end{array}$ & $\begin{array}{l}0.00014 \\
(2.00)\end{array}$ \\
\hline initial per capita GDP & $\begin{array}{l}-0.0088 \\
(-3.61)\end{array}$ & $\begin{array}{l}-0.0172 \\
(-5.70)\end{array}$ \\
\hline \multicolumn{3}{|c|}{$\begin{array}{l}\text { Summary of Variance Estimates } \\
\text { (All variance numbers are multiplied by 1000) }\end{array}$} \\
\hline Mean variance & 3.58 & 0.99 \\
\hline Lowest variance country & $\begin{array}{c}0.317 \\
\text { (Sweden) }\end{array}$ & $\begin{array}{c}0.299 \\
\text { (Norway) }\end{array}$ \\
\hline Highest variance country & $\begin{array}{c}28.7 \\
\text { (Iraq) }\end{array}$ & $\begin{array}{c}2.90 \\
\text { (Turkey) }\end{array}$ \\
\hline U.S. Variance & 0.663 & 0.596 \\
\hline $\begin{array}{l}\text { Percent of countries with } \\
\text { variances different from the } \\
\text { U.S. at } 10 \text { percent significance } \\
\text { level. }\end{array}$ & $65.9 \%$ & $52.2 \%$ \\
\hline log of likelihood function & 3589.4 & 1883.8 \\
\hline
\end{tabular}


Table 2

Relationship between Mean Growth and Innovation Volatility ( $t$-statistics in parentheses)

\section{Maximum Likelihood Estimation}

\begin{tabular}{|c|c|c|}
\hline constant & $\begin{array}{l}0.0607 \\
(3.58)\end{array}$ & $\begin{array}{c}0.294 \\
(8.65)\end{array}$ \\
\hline volatility $(\sigma)$ & $\begin{array}{r}-0.178 \\
(-2.43)\end{array}$ & $\begin{array}{l}-0.949 \\
(-4.09)\end{array}$ \\
\hline $\begin{array}{l}\text { Initial investment } \\
\text { share of GDP }\end{array}$ & $\begin{array}{c}0.019 \\
(1.37)\end{array}$ & $\begin{array}{c}0.057 \\
(2.67)\end{array}$ \\
\hline $\begin{array}{l}\text { Initial population } \\
\text { growth rate }\end{array}$ & $\begin{array}{r}0.000 \\
(0.13)\end{array}$ & $\begin{array}{r}0.615 \\
(2.85)\end{array}$ \\
\hline initial human capital & $\begin{array}{l}0.0012 \\
(2.01)\end{array}$ & $\begin{array}{l}0.00015 \\
(2.23)\end{array}$ \\
\hline initial per capita GDP & $\begin{array}{l}-0.023 \\
(-4.46)\end{array}$ & $\begin{array}{l}-0.0032 \\
(-0.62)\end{array}$ \\
\hline $\log (\operatorname{gdp}(-1))$ & $\begin{array}{l}0.218 \\
(10.8)\end{array}$ & $\begin{array}{c}0.084 \\
(2.76)\end{array}$ \\
\hline $\log (\operatorname{gdp}(-2))$ & $\begin{array}{r}-0.200 \\
(-9.34)\end{array}$ & $\begin{array}{l}-0.113 \\
(-3.86)\end{array}$ \\
\hline post-73 dummy & $\begin{array}{l}-0.0108 \\
(-3.19)\end{array}$ & $\begin{array}{l}-0.0255 \\
(-6.62)\end{array}$ \\
\hline trend & $\begin{array}{l}-0.00027 \\
(-0.222)\end{array}$ & $\begin{array}{l}0.0015 \\
(1.77)\end{array}$ \\
\hline trend squared & $\begin{array}{l}-0.00001 \\
(-0.169)\end{array}$ & $\begin{array}{l}-0.0000 \\
(-0.0018)\end{array}$ \\
\hline post -73 trend & $\begin{array}{l}-0.0009 \\
(-0.448)\end{array}$ & $\begin{array}{l}-0.00029 \\
(-0.241)\end{array}$ \\
\hline \multicolumn{3}{|l|}{ 2. Two-Step Estimation } \\
\hline volatility $(\sigma)$ & $\begin{array}{l}-0.113 \\
(-0.73)\end{array}$ & $\begin{array}{l}-0.823 \\
(-3.58)\end{array}$ \\
\hline
\end{tabular}

Note: The $\mathrm{L}-\mathrm{R}$ and forecast variables were also included in the two-step procedure, but their coefficients are not reported for the sake of brevity. 
Table 3

Examination of Investment and Innovation Volatility

( $t$-statistics in parentheses)

92 Country Sample

(2208 observations)

OECD Country Sample

(888 observations)

1. Growth Equations: Coefficient on Volatility

\section{Investment variable}

included:

Initial investment

share of GDP

$(-2.43)$

$-0.949$

Average investment

share of GDP

$-0.169$

$(-2.33)$

$(-4.09)$

None

$-0.175$

$-0.961$

$(-4.16)$

$(-2.38)$

$-0.987$

$(-4.06)$

Note: The other $\mathrm{L}-\mathrm{R}$ variables, lagged GDP and time trends were also included.

\section{Investment Equations: Coefficient on Volatility}

Other variables included

(besides a constant term):

None

$$
\begin{array}{r}
-0.489 \\
(-1.66)
\end{array}
$$

Other $\mathrm{L}-\mathrm{R}$ variables 
Table 4

Effect of Government Spending-Induced Volatility

$(t-s t a t i s t i c s$ in parentheses)

Effect of:

(2)

(3)

(4)

$(5)$

92-Country Sample

\begin{tabular}{lccccc}
\hline $\begin{array}{l}\text { volatility on } \\
\text { growth }(\lambda \text { in }(2 \mathrm{a}))\end{array}$ & $-3.53^{*}$ & -0.166 & $-0.220^{*}$ & -0.166 & -0.187 \\
& $(-1.47)$ & $(-1.35)$ & $(-1.83)$ & $(-1.36)$ & $(-1.32)$ \\
$\begin{array}{l}\text { Government volat. } \\
\text { on output volat. }\end{array}$ & 0.611 & 0.647 & 0.614 & 0.658 & 0.430 \\
$\left(\alpha_{1}\right.$ in $\left.(2 \mathrm{~b})\right)$ & $(20.0)$ & $(19.3)$ & $(19.1)$ & $(18.5)$ & $(15.4)$
\end{tabular}

\section{OECD Sample}

\begin{tabular}{|c|c|c|c|c|c|}
\hline $\begin{array}{l}\text { volatility on } \\
\text { growth }(\lambda \text { in }(2 a))\end{array}$ & $\begin{array}{l}-0.525 \\
(-1.97)\end{array}$ & $\begin{array}{l}-0.454 \\
(-1.80)\end{array}$ & $\begin{array}{r}-0.470 \\
(-2.04)\end{array}$ & $\begin{array}{l}-0.426 \\
(-1.93)\end{array}$ & $\begin{array}{l}-0.474^{*} \\
(-2.17)\end{array}$ \\
\hline $\begin{array}{l}\text { Government volat. } \\
\text { on output volat. } \\
\left(\alpha_{1} \text { in }(2 b)\right)\end{array}$ & $\begin{array}{l}0.527 \\
(6.9)\end{array}$ & $\begin{array}{l}0.534 \\
(6.9)\end{array}$ & $\begin{array}{l}0.625 \\
(7.7)\end{array}$ & $\begin{array}{c}0.624 \\
(7.5)\end{array}$ & $\begin{array}{l}0.593 \\
(7.9)\end{array}$ \\
\hline
\end{tabular}

Variables Included in Growth Equation

\begin{tabular}{lccccc}
\hline $\begin{array}{l}\text { country fixed } \\
\text { effects }\end{array}$ & no & yes & no & yes & yes \\
$\begin{array}{l}\text { time fixed } \\
\text { effects }\end{array}$ & no & no & yes & yes & yes \\
growth of govt & no & no & no & no & yes \\
\hline
\end{tabular}

Joint estimation using estimated squared goverment spending forecast errors as regressors. All specifications include a constant term and two lags of $\log$ GDP. The $\mathrm{L}-\mathrm{R}$ variables are included when country fixed effects are excluded and the trend variables are included when time fixed effects are excluded. Estimates denoted by ${ }^{*}$ indicate that due to convergence problems, the model had to be estimated in two steps. First, the model was estimated by maximum likelihood with $\lambda$ set to zero. The estimated standard deviations from this first step were then included as variables in the mean equation and the model was re-estimated. 


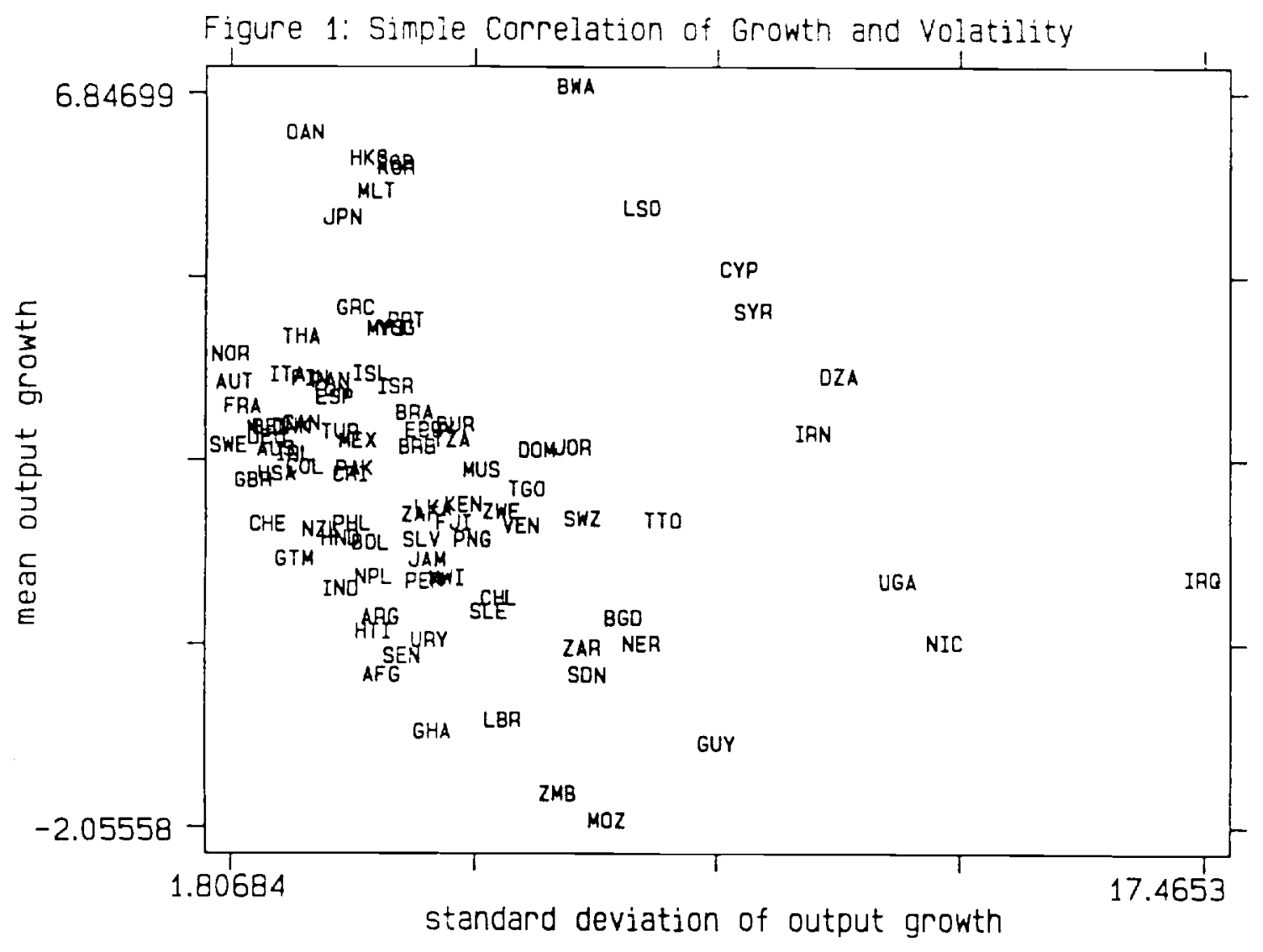


Figure 2: Partial Correlation of Growth and Volatility: OECD (controlling for the Levine-Renelt variables)

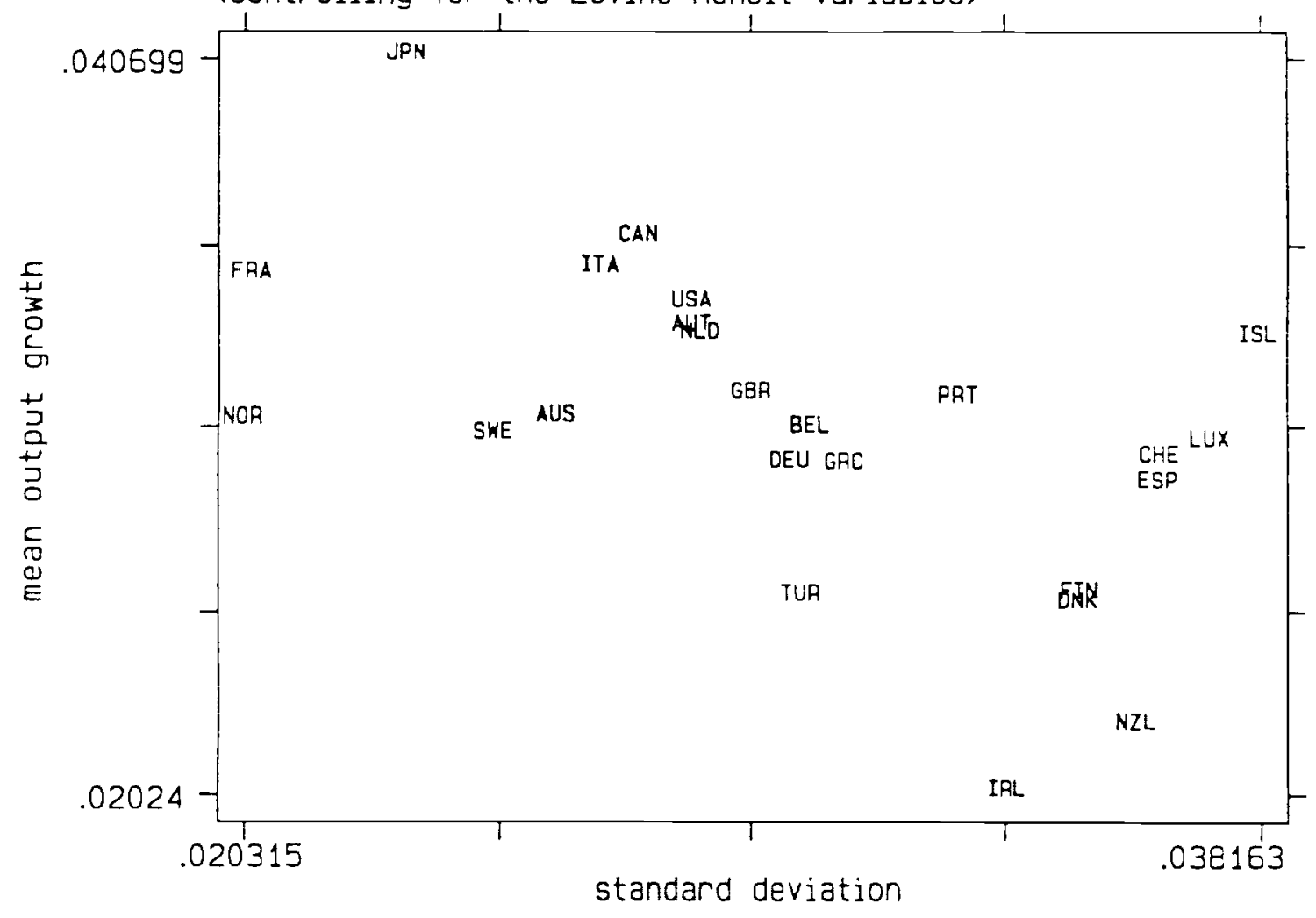

